\title{
THE USE OF FLOGGING AS A PUNISHMENT IN SAUDI ARABIA FROM THE PERSPECTIVE OF INTERNATIONAL HUMAN RIGHTS LAW
}

\author{
Hind Sebar* \\ Shahrul Mizan Ismail**
}

\begin{abstract}
Flogging is one of the most widely-used corporal punishments in Islamic penology. Most countries that practice Islamic criminal law use flogging to punish a variety of crimes and offenses. Saudi Arabia is one of the countries that use flogging to punish various crimes and has faced immense backlash from the international community for gross violation of human rights. The goal of this article is to investigate the implementation of flogging as a punishment in Saudi Arabia. Moreover, it also examines how international human rights law has contributed to limiting flogging as a form of criminal punishment. This study has critically analysed several human rights documents in order to understand how flogging is viewed under international human rights law if compared to the position under the Shari'ah. Focus on the implementation of flogging in Saudi Arabia is made in particular. In addition, it is found that the application of flogging in Saudi Arabia is overused and is uncodified. Hence, the article signifies the necessity of codifying the Islamic law to ensure fair legal procedures. Interestingly, a recent announcement that abolishes flogging as a common form of punishment, indicates the willingness of the kingdom to implement judicial reforms, thereby creating a ray of hope in the form of amendment of laws.
\end{abstract}

Keywords: $\quad$ flogging, Saudi Arabia, international human rights law, Islamic penology, Shari'ah.

* Postgraduate student at Faculty of Law, National University Malaysia. Email: hindalsbbar@gmail.com.

** Associate Professor at Faculty of Law, National University Malaysia. Email: shahrulmizan@ukm.edu.my. 


\title{
PENGGUNAAN SEBATAN SEBAGAI HUKUMAN DI ARAB SAUDI DARI PERSPEKTIF UNDANG-UNDANG HAK ASASI ANTARABANGSA
}

\begin{abstract}
ABSTRAK
Sebatan adalah salah satu hukuman yang digunakan secara meluas dalam penologi Islam. Sebilangan besar negara yang mengamalkan undangundang jenayah Islam menggunakan hukuman sebatan untuk menghukum pelbagai jenayah dan kesalahan. Arab Saudi adalah salah satu negara yang menggunakan hukuman ini dan telah menghadapi respon dan kritikan hebat daripada pelbagai pihak. Matlamat kajian ini adalah untuk menyiasat pelaksanaan hukuman sebat sebagai hukuman jenayah di Arab Saudi. Ia juga mengkaji bagaimana undang-undang hak asasi manusia antarabangsa telah menyumbang dalam membataskan penggunaan hukuman sebat sebagai satu bentuk hukuman jenayah. Kajian ini menggunakan kaedah analisis perbandingan berdasarkan kualitatif untuk membandingkan konsep sebatan dalam undang-undang Hak Asasi Manusia Antarabangsa dan dalam undang-undang Syariah, dengan memfokus pada pelaksanaannya di Arab Saudi. Akhirnya, kajian ini menyimpulkan bahawa pemakaian hukuman sebat di Arab Saudi adalah terlalu banyak digunakan dan tidak diwartakan secara jelas dalam peruntukan undang-undang jenayah. Walaubagaimanapun, pengumuman baru-baru ini yang menghapuskan sebatan sebagai bentuk hukuman yang umum menunjukkan reformasi kehakiman yang telah menciptakan sinar harapan untuk perubahan undang-undang.
\end{abstract}

Kata kunci: $\quad$ sebatan, Arab Saudi, undang-undang hak asasi antarabangsa, penologi Islam, undang-undang Syariah.

\section{INTRODUCTION}

Many countries today resort to corporal punishments to penalize perpetrators. The use of such punishments is often grounded in explanations from their domestic and religious laws. However, corporal punishments are against the rules and norms of international human rights law and have been pronounced as strictly prohibited. Following World War II, human rights started to take center-stage on global and regional levels. Consequently, their increasing importance ensued in the passing of the Universal Declaration of Human Rights (UDHR) in 1948. The UDHR is regarded as one of the most significant documents in the history of human rights and an ultimate source of 
various conventions, covenants, and treaties for the protection of human rights.

Article 5 of the Declaration asserts that no one should be subjected to any physical form of torture or cruel, inhuman, or degrading treatment or corporal punishment. One of the most common corporal punishments is flogging. Islamic penology also consists of various forms of corporal punishments. Most countries that practice Islamic criminal law use flogging to punish a variety of crimes and offenses. Saudi Arabia is one of those countries that use flogging to punish various crimes and has faced immense backlash from the international community for gross violation of human rights.

The goal of this study is to evaluate the existing situation of flogging in Saudi Arabia as a punishment from the perspective of UDHR. Moreover, it sheds light on how international human rights law has attempted to limit the use of flogging as a form of punishment. This study has critically analysed the international human rights documents in order to understand the concept of flogging. A comparison is then made with the position under the Shari'ah. Subsequently, the study expounds on the implementation of flogging in Saudi Arabia.

The study has discovered that the application of flogging in Saudi Arabia is uncodified. However, Saudi Arabia has shown an inclination towards reforming its legal system to make it consistent with acceptable international legal practices. A significant contribution of this study is that it points out how uncodified law, for example, in Saudi Arabia, can lead to serious human rights abuses and in the absence of inscribed rules, regulations, and laws, justice can never be achieved in a consistent manner. Overall, this study is beneficial to acquire an in-depth understanding of the judicial and criminal system of Saudi Arabia.

\section{FLOGGING: AN INTRODUCTION}

The concept of punishment and its practical implementation during the $20^{\text {th }}$ century has transformed from punishing the offenders to reforming them. Punishment is now a retributive procedure. The modern criminal justice system is greatly influenced by Anglo-American criminology, which had laid foundation for the theoretical framework for the understanding of crime, legislation, and social control. However, many 
other advanced nations, especially in the European Union, have now made many contributions to criminology to make their criminal justice systems retributive in nature. However, even today, many nation states such as Nigeria, Saudi Arabia, UAE, Iran, Pakistan, Qatar and Sudan resort to corporal punishments to penalize the criminals. But on numerous global forums, these nations using corporal punishments have faced a lot of criticism, owing to their blatant violations of human rights law.

Flogging is one such corporal punishment. Oxford learner's dictionary defines flogging "as a punishment in which somebody is hit many times with a whip or stick". Encyclopedia Britannica defines flogging as follows:

Flogging, also called whipping or caning, a beating administered with a whip or rod, with blows commonly directed to the person's back. It was imposed as a form of judicial punishment and as a means of maintaining discipline in schools, prisons, military forces, and private homes". ${ }^{2}$ In Arabic it can be called as Jalad, which means to strike with repeated strokes, as with a strap, rod or a lash.

International human rights law prohibits those verdicts which impose corporal punishments, such as flogging with the pretext of inhumane and torturous treatment. Many global human rights treaties, such as the Universal Declaration of Human Rights (UDHR), the United Nations Convention against Torture (UNCAT) and the International Covenant on Civil and Political Rights (ICCPR) also prohibit "cruel, inhuman, or degrading treatment or punishment". Although the human rights law has diminished the use of flogging as a punishment, it is rampantly being used as a form of punishment in many Muslim-majority nations that use the Shari 'ah law. Although in principle, every nation state is obliged to comply with the international laws and treaties, their implementation suffers from the absence of any centralized enforcement authority and supremacy of domestic constitutions in the name of sovereignty. Nonetheless, in case of international treaties, the member states cannot be enforced to implement the obligations. However, the international justice system can obligate countries to provide access in case of human rights violations. Therefore, the

1 Oxford Online Dictionary, Flogging, 2020, Retrieved from https://en.oxforddictionaries.com/definition/ (visited in 18/11/2020).

2 Abbott, Geoffrey. "Flogging". Encyclopedia Britannica. November 14, 2014 https://www.britannica.com/topic/flogging. 
implementation of international treaties depends largely on the approval of member states. Hence, the authority of international law has to follow the consent of domestic authorities. Article 2 of the International Convention of Civil and Political Rights (ICCPR) states that:

Where not already provided for by existing legislative or other measures, each State Party to the present Covenant undertakes to take the necessary steps, in accordance with its constitutional processes and with the provisions of the present Covenant, to adopt such legislative or other measures as may be necessary to give effect to the rights recognised in the present Covenant.

Thus, many nations can still legalize the corporal punishment in their domestic law.

However, some states, such as Singapore are using it beyond the aegis of Shari'ah law. Flogging represents the punishments that cause pain, and it has been categorized as a kind of torture. However, the prohibition of torture has been considered as a violation of basic human right in the Article 5 of the UDHR, Article 7 of the ICCPR, Article 5 of the American Convention on Human Rights (ACHR) and numerous other regional treaty documents. It is defined and prohibited by Article 1 of the United Nations Convention Against Torture (UNCAT) and Other Cruel, Inhuman or Degrading Treatment or Punishment. The article states that:

Any act by which severe pain or suffering, whether physical or mental, is intentionally inflicted on a person for such purposes as obtaining from him or a third person information or a confession, punishing him for an act he or a third person has committed or is suspected of having committed, or intimidating or coercing him or a third person, or for any reason based on discrimination of any kind, when such pain or suffering is inflicted by or at the instigation of or with the consent or acquiescence of a public official or other person acting in an official capacity. ${ }^{3}$

In addition, Manfred Nowak, the UN Special Rapporteur on Torture, asserts that all kinds of corporal punishment under the International

3 "Convention Against Torture and Other Cruel, Inhuman or Degrading Treatment or Punishment," United Nations and the Rule of Law. https://www.un.org/ruleoflaw/blog/document/convention-againsttorture-and-other-cruel-inhuman-or-degrading-treatment-orpunishment/. 
Human Rights Law are considered as a form of "cruel, inhuman or degrading punishment". ${ }^{4}$ His statement about the corporal punishment is given as follows:

What is common to all forms of corporal punishment is that physical force is used intentionally against a person in order to cause a considerable level of pain. Furthermore, without exception, corporal punishment has a degrading and humiliating component. All forms of corporal punishment must be considered as amounting to cruel, inhuman or degrading punishment in violation of international treaty and customary law. ${ }^{5}$

From human rights perspective, flogging as a judicial punishment intends to cause pain and harm to the offender, and if it is imposed in public, it inflicts the feelings of shame and humiliation; ${ }^{6}$ hence, it falls under the concept of "torture" as it causes clear physical pain, suffering and mental trauma.

\section{FLOGGING AS PUNISHMENT IN THEORY AND MODERN PRACTICES}

Historically, flogging had been one of the most widely used punishments in various legal systems. Offenses punished by flogging range from maintaining discipline in schools and homes to the punishments of serious crimes.

4 Dennis, Michael J. "The Fifty-Third Session of the UN Commission on Human Rights." American Journal of International Law 92, no. 1 (1998): 112-24. doi:10.2307/2998071.

5 UN Human Rights Council, Report of the Special Rapporteur on torture and other cruel, inhuman or degrading treatment or punishment, 5 March 2015, A/HRC/28/68, available at: https://www.refworld.org/docid/550824454.html [accessed 26 June 2021].

6 Iakobishvili, Eka. Inflicting harm: Judicial corporal punishment for drug and alcohol offences in selected countries (Report) International Harm Reduction Association, 2011. Available at, http://fileserver.idpc.net/library/IHRA-Inflicting-Harm-2011.pdf (Accessed 29/4/2021). 
Judicial systems rely on various theories to support the usage of punishment to maintain law and order in society. ${ }^{7}$ The theories of punishment stem from two basic philosophies, namely, utilitarianism and retributive justice. The utilitarian theory of punishment seeks to punish criminals in order to discourage and deter them from committing any future offenses. It points out that punishments have consequences for both the offender and the society. From this perspective, the purpose of punishment is to deter criminals from committing crimes and setting an example for society.

The chief proponent of the utilitarian concept in punishment theory is Jeremy Bentham (1748-1832), who is widely regarded as a pioneering political theorist in Anglo-American legislation philosophy. His basic argument in support of Utilitarian theory is that sentences should be sufficient to deter other members of the society from committing the offense. ${ }^{8}$ Hence, the utilitarian view prioritizes the common societal good over individual interest. In the utilitarian view, the interest of the community is favorable. For utilitarianism, the costs of punishment in terms of utility are exceeded by the gains in utility by punishment. For them, the punishments are inflicted to achieve three elements:

(a) Pure is cost-benefit,

(b) Deterrence,

(c) Rehabilitation. ${ }^{9}$

In the famous post-Bentham works, an Austrian jurist Hans Kelsen (1881-1973) and a British legal philosopher Herbert Hart (1907-1992) laid the foundation for legal realism. In their view, the process of jurisprudence must consider empirical proofs by using scientific methods to justify any conviction.

7 Meyer, Joel. "Reflections on some theories of punishment." The Journal of Criminal Law, Criminology, and Police Science 59, no.4 (1968): p.595.

8 Crimmins, James E. "A Hatchet for Paley's Net": Bentham on capital punishment and judicial discretion, Canadian Journal of Law and Jurisprudence Vol. I, No. 1 (January 1988). P 73. Doi: https://doi.org/10.1017/S0841820900000606.

9 Ramzan, Shazia, Naseem Akhter, and Ainee Rubab. "Punishment from Islamic perspective." FWU Journal of Social Sciences 9, no. 1 (2015): 53. 
On the other hand, the retributive theory of punishment relies on a classic legal concept of lex talionis, a Latin phrase, which literally means, "eye for an eye". Lex talionis asserts that the punishment should cause the offender what he did to others. The retributive theory claims that the sentence, therefore, serves as a means of giving perpetrators what they have done to others. ${ }^{10}$ The retributive theory aims to punish the offenders because they deserve it and the criminal behavior disturbs the peace of society and offenders should be punished to maintain peace in society.

The famous German philosopher and pioneering enlightenment theorist, Immanuel Kant (1724-1804) highlighted the importance of motivation and reason behind the crime. His theory assumes that people are pragmatic and capable of making logical decisions, therefore, they must be held responsible for their actions. The Retributive Theory considers the crime to be the reason for punishment. However, it has been criticized because morality is subjective, and it is difficult to punish for crimes. American philosopher Herbert Morris (b. 1928) argues that the laws under Retributivist Theory should ensure that they would take any gain or good from the offender that he took illegally or without an appropriate cost.

The use of corporal punishments has gradually been reduced due to the international human rights law and liberal influences. Over the past few decades, reformatory prisons are gradually replacing these punishments. However, even today, many judicial systems are using flogging to punish the perpetrators. ${ }^{11}$ The use of flogging dates back to the $19^{\text {th }}$ century colonial era. It was widely implemented in colonial territories where colonial people were subjected to inhuman treatment such as flogging. The Australian historian, Professor Amanda Nettel Beck argues that, "Around Britain's Empire, colonized people remained subject to flogging as a judicial punishment long after it

10 Rashdall, Hastings. "The ethics of forgiveness." The International Journal of Ethics 10, no. 2 (1900). Doi:10.1086/intejethi.10.2.2376034. p.193.

11 Iakobishvili, Eka. Inflicting harm: Judicial corporal punishment for drug and alcohol offences in selected countries (Report) International Harm Reduction Association, 2011. (Accessed 2/5/2021)http://fileserver.idpc.net/library/IHRA-Inflicting-Harm2011.pdf. 
declined in application to other groups". ${ }^{12}$ Furthermore, Stephen and Annie claim that "it was a powerful deterrent, justified by the brutal nature of the 'savages' to whom it was applied". ${ }^{13}$

\section{Flogging as a Punishment in International Human Rights Law}

International human rights law explicitly prohibits judicial punishments involving corporal punishments, such as flogging because these punishments involve torture and ill-treatment. The Universal Declaration on Human Rights (UDHR) states in Article 5, "No one shall be subjected to torture or to cruel, inhuman or degrading treatment or punishment". ${ }^{14}$ Article 5 of the UDHR aims to give every individual a right not to be subjected to ill-treatment. After the approval of the UDHR in 1948, "many of its goals were understood as aspirational" 15 and consequently, several international channels also started to impose its mandatory obligation.

Similarly, the United Nations Convention Against Torture (UNCAT) also prohibits torture, cruel, and inhuman punishments. It is aimed to enhance the deterrence of torturous practices. The UNCAT was passed in 1984. Primarily, it obligates the states to take effective legislative, administrative, and judicial measures to prevent torture in any territory under their jurisdiction. The article 2.1 of the UNCAT states that "each State shall take effective legislative, administrative, judicial or other measures to prevent acts of torture in any territory

12 P. Dwyer and A. Nettelbeck (eds.), Violence, Colonialism and Empire in the Modern World, Cambridge Imperial and Post-Colonial Studies Series, https://doi.org/10.1007/978-3-319-62923-0_6, p.112.

13 Peté, Stephen, and Annie Devenish. "Flogging, Fear and Food: Punishment and Race in Colonial Natal." Journal of Southern African Studies 31, no. 1 (2005): 3-21. Accessed June 26,2021. http://www.jstor.org/stable/25064970.

14 Johannes van Aggelen, The Preamble of the United Nations Declaration of Human Rights, 28 Denver Journal of International Law \& Policy, (2000), p.129.

15 Dunn, Shannon. "Islamic Law and Human Rights." In the Oxford Handbook of Islamic Law, ed Anver M. Emon and Rumee Ahmed (Oxford University Press: 2018). (Accessed 17/4/2021) https://www.oxfordhandbooks.com/view/10.1093/oxfordhb/9780199679 010.001.0001/oxfordhb-9780199679010-e-26?mediaType=Article. 
under its jurisdiction". ${ }^{16}$ Additionally, in article 4, it encourages the member states to make sure that their legislative laws do not use torture. More specifically, the article 4 states that:

Each State Party shall ensure that all acts of torture are offenses under its criminal law. The same shall apply to an attempt to commit torture and to an act by any person which constitutes complicity or participation in torture. Each State Party shall make these offenses punishable by appropriate penalties which takes into account their grave nature. ${ }^{17}$

Different UN organs like the United Nations Human Rights Council (UNHRC) and UN High Commissioner for Human Rights have clearly deemed that flogging amounts to inhumane, degrading, and cruel punishment. The human rights committee was established under Article 28 of the International Covenant on Civil and Political Rights (ICCPR). It should be noted that Saudi Arabia is neither a party nor a signatory to the ICCPR, although it claims to respect all the human rights clauses in the covenant. Therefore, Saudi Arabia has legalized flogging in its criminal justice system, despite the fact that the ICCPR has banned any physical punishment to the criminals, thereby calling it a type of torture. Article 7 of the ICCPR bans all types of degrading treatments to human beings and reaffirms the UDHR's proscription of torture. This article states that, "The freedom from inhuman or degrading treatment or punishment" ${ }^{18}$ In Osbourne v. Jamaica, ${ }^{19}$ the Human Rights Committee (HRC) has stated,

Irrespective of the nature of the crime that is to be punished, however brutal it may be, it is the firm opinion of the Committee that corporal punishment constitutes cruel, inhuman and degrading treatment or punishment contrary to Article 7 of the Covenant.

16 "Convention Against Torture and Other Cruel, Inhuman or Degrading Treatment or Punishment", United Nations Treaty Series, accessed December 1,2020. http https://treaties.un.org/.

17 Ibid

18 "The International Covenant on Civil and Political Rights (ICCPR)".

United Nations Human Rights Office of the Commissioner. Accessed December 2, 2020.

https://www.ohchr.org/en/professionalinterest/pages/ccpr.aspx.

19 "George Osbourne v. Jamaica", University of Minnesota Human Rights Library. Accessed December 2, 2020. http://hrlibrary.umn.edu/undocs/session68/view759.htm. 
The Human Rights Committee (HRC) noted in its General Comment 20 to Article 7 of the International Covenant on Civil \& Political Rights (ICCPR) that the said prohibition extends to "corporal punishment, including excessive chastisement ordered for a crime." 20

In addition, there are many non-governmental organizations (NGOs) that are working to strengthen international efforts to curb torturous punishments globally. Some of the notable international NGOs working in this regard are the Amnesty International, Association for the Prevention of Torture, International Federation of ACAT (Action of Christians for the Abolition of Torture), International Federation of Human Rights Leagues, Human Rights Watch, International Commission of Jurists, International Rehabilitation Council for Torture Victims, International Service for Human Rights, and World Organization against Torture.

Saudi Arabia was one of the 8 countries that refrained from the UN General Assembly vote on the UN Declaration of Human Rights, ${ }^{21}$ and it did not ratify the International Covenant on Civil and Political Rights (ICCPR) adopted in in 1966. Moreover, it is also not a member of the International Covenant on Economic, Social and Cultural Rights (ICESCR). These two conventions impose obligations that are driven by the Universal Declaration on Human Rights. In 1997, Saudi Arabia had acceded to UNCAT, but it had not recognized the jurisdiction of some committees of the convention. The kingdom has been put to multiple reviews (latest in 2016) by the convention members to reform its judicial system. The United Nations Convention against Torture (UNCAT) had insisted Saudi Arabia to revisit its policies regarding corporal punishments to prohibit flogging as a punishment. The ICCPR $^{19}$ emphasizes on all the UN member states to codify the human rights, which have been approved by various regional and international agreements. Apart from the codification of the other human rights, the prevention of torture is codified in many international treaties. More specifically, codification of torture prohibition is stated in Article 7 of

20 "Compilation of General Comments and General Recommendations adopted by human rights treaty bodies: note / by the Secretariat". United Nations Digital Library accessed December 2, 2020. https://digitallibrary.un.org/record/576098?ln=en. 
the ICCPR, Article 5 of UDHR, Article 5 of the American Convention on Human Rights (ACHR) and many other regional treaty documents.

The United Nation's Universal Periodic Review lists some of recommendations to urge Saudi Arabia to implement more strict policy for imposing corporal punishments. Saudi Arabia had accepted Belarus recommendation which stated: "Adopt further steps to prevent torture, cruel and degrading treatment in prisons and detention centers", 22 moreover, it tagged Estonia recommendation as "noted" where the latter suggest that the Saudi government, "Abolish all forms of corporal punishment for all persons, including children and detainees, in all settings". ${ }^{23}$

The list of UNUPR recommendations have clearly emphasized the need for Saudi Arabia to abolish corporal punishments in its criminal justice system. Since Saudi Arabia is a UN member state, it needs to consider the recommendations or face more pressure from international human rights organizations including the UN. Although the international treaties cannot be forcibly implemented in any member states including Saudi Arabia, but a continuous disregard of these recommendations puts the country under the constant scanner of human rights organizations.

\section{FLOGGING UNDER THE SHARI'AH}

\section{A Brief Introduction of the Islamic System of Penology.}

By definition, a penological system is a branch of criminology, which relates to the management of prisons and the rehabilitation of criminals inside a prison. However, in broader scope, this field is not just limited to prisons, but it provides the theoretical framework and practical implementation of the rehabilitation process of prisoners beyond their incarceration period. Therefore, substantive laws are legislated to institute various rights and responsibilities by state institutions.

\footnotetext{
22 "Responses to Recommendations, Saudi Arabia Session 31 Review in the Working Group". The Universal Periodic Review. Accessed December 3, 2020. https://www.uprinfo.org/sites/default/files/document/saudi_arabia/session_31__november_2018/2rps_saudi_arabia_31upr.pdf. Ibid.
} 
Moreover, procedural laws are defined to implement the substantive laws in the justice system.

In the Islamic tradition, the punishments have been considered as retributive in nature. Primarily, the punishments in Islamic criminal law are divided into three categories: Hudûd (fixed punishments), Qisâs (restitutionary) and Tazir (discretionary) ${ }^{24}$. The Sharia laws are derived from the Quran and Sunnah of the Holy Prophet (PBUH). Islamic penal system describes three different types of punishments as follows: prescribed, retribution, and discretionary punishments. ${ }^{25}$

Under the Shari'ah, the word 'Hadd' literally means 'restriction' or 'limit'. Hadd is often used in Islam for the limits of suitable behavior and for the punishment of serious offenses. In Islamic penology, hadud refers to a plurality of punishments which are fixed for only 7 types of crimes. These punishments are the rights of God and rights of an individual and they are implemented for the collective well-being of the society against any member of society who commits the crime. ${ }^{26}$ Hudud punishment is based on the idea of deterring other individuals from committing such a crime. Hadd is a singular form of Hudud, meaning "prevention, hindrance, restraint, prohibition, and hence a restrictive ordinance or statute of God, respecting things lawful and unlawful". ${ }^{27}$ The second form of Islamic punishments is called Qisas (or retaliation): a punishment for murder and personal injury under Islamic law. It means that the infliction of injury (or murder) on the victim must be equal to the infliction of injury (or murder) on the culprit. The third form, Ta'zir (discretionary) is the punishment that is inflicted for actions that are considered sinful in Islam.

The bulk of punishments in Islamic law comes under the umbrella of Ta'zir. Some of the most common types of Ta'zir are imprisonment, fines, death penalty, and whipping. However, the sole reason for inflicting any sort of punishment in Shari'ah is achieving

24 Ramzan, Shazia, Naseem Akhter, and Ainee Rubab. "Punishment from Islamic Perspectives." FWU Journal of Social Sciences 9, no. 1 (2015): p.53.

25 Ibid.

26 Candra, Marli. "The Penology of Islamic Criminal Law: Reintroduction of Islamic Penology." AL-'ADALAH 15, no. 2 (2018), p. 359.

27 al-Nisapuri, Abul Husain. "Kitab Al Hudud". International Islamic University, Accessed December 12, 2020. https://www.iium.edu.my/deed/hadith/muslim/017_smt.html. 
justice. General and special deterrence take precedence over rehabilitation in Hadd and Qishash punishment, as evidenced by the fact that the penalty is usually carried out publicly and immediately. As for Ta 'zir punishments, the consensus among scholars is that their basic goal is to create discipline and correction in the society, which includes any punishment that the ruler or judge finds appropriate. ${ }^{28}$

\section{Flogging as a Punishment in Islam}

In the Holy Quran, flogging has been mentioned in verse 2 of Surah Al-Nur as a punishment for adultery:

As for female and male fornicators, give each of them one hundred lashes and do not let pity for them make you lenient in 'enforcing' the law of Allah if you 'truly' believe in Allah and the Last Day. And let a number of believers witness their punishment. ${ }^{29}$

In the same context, verse 4 of Surah Al-Nur also mentions flogging as a punishment for anyone who accuses women for committing adultery but fails to bring 4 male, Muslim witnesses, as found in the following verse:

Those who accuse chaste women 'of adultery' and fail to produce four witnesses, give them eighty lashes 'each'. And do not ever accept any testimony from them - for they are indeed rebellious. ${ }^{30}$

Hudud crimes punishable by flogging are adultery or fornication (termed as Zinā) for non-married partners. If proven, these crimes are punished with 100 lashes. Accusing someone of fornication (Qazf) falsely and accusing somebody of adultery or sodomy is punishable by 80 lashes, and consuming intoxicants (shrub alkhamr) is punishable by 40 lashes as mentioned in the Hadith. ${ }^{31}$ However, Caliphs Umar and Ali subsequently increased this

28 Candra, Marli. 2019. "The Penology of Islamic Criminal Law: Reintroduction of Islamic Penology". AL-'ADALAH 15 (2): 363. Raden Intan State Islamic University of Lampung. doi:10.24042/adalah.v15i2.2783.

29 Quran, Nur. Verse 2. Translated by Dr. Mustafa Khattab, the Clear Quran

30 Quran, Nur. Verse 2. Translated maj

31 Al-Nisapuri, Abul Husain."Kitab Al Hudud". International Islamic University, Accessed December 12, 2020. https://www.iium.edu.my/deed/hadith/muslim/017_smt.html. 
punishment to 80 lashes after consultation with other companions. ${ }^{32}$ Therefore, the minimum number of lashes in Hudud is 40 and the maximum number of lashes is 100 .

However, flogging became one of the most widely-used punishments in later periods of Islamic history when ijtihad opened the doors for interpretations of judicial rulings based on the Shari'ah, following the Holy Prophet's (PBUH) demise. In case of flexible punishments like 'Ta'zir', a judge has been granted the responsibility of determining punishments, however, in fixed punishments like Hadd and Qisas, judges do not have the authority or jurisdiction to increase or decrease the prescribed punishments, as these punishments have been prescribed and specified in the Qur'an and Sunnah. In the case of flogging, it is also a punishment under Ta'zir (or discretionary punishments). Historically, it has been practiced as a chosen punishment for many offenses under various interpretations of the Shari'ah.

\section{The Rules and Limitations of using flogging under the Shari'ah}

$H u d u d$ crimes cannot be reduced, tolerated, and waived because those punishments are based on the right of God. These are the limits ordained by God, therefore they cannot be transgressed. Flogging in Hadd punishments as demonstrated by the Qur'an and Sunnah is a punishment for offenses like adultery, sexual slander, and drinking. The evidence needed for these offenses gives perpetrators the right to not be accused if the prescribed procedures are followed. Hence, flogging outside Hudûd can also appear in Ta'zir. Its implementation depends upon the decision of the judge.

The main principle in the application of Hudud punishments is the maximization of mercy. Flogging as a punishment in Hadd has certain limitations. This was devised in a Hadith attributed to Holy Prophet (PBUH) and was also told by his wife Aisha. It states that, "Ward off the Hudûd from the Muslims as much as you all can, and if

32 Brown, Jonathan. 2017. "Stoning and Hand Cutting-Understanding the Hudud and the Shariah in Islam, Yaqeen Institute for Islamic Research". Yaqeen Institute for Islamic Research. Accessed May 23 2021. https://yaqeeninstitute.org/jonathan-brown/stoning-and-handcutting-understanding-the-hudud-and-the-shariah-in-islam. 
you find a way out for the person, then let them go. For it is better for the authority to err in mercy than to err in punishment". ${ }^{33}$ A century following the Holy Prophet's (PBUH) demise, this Hadith became a crucial legal principle in Islamic law, "Ward off the Hudûd by ambiguities (shubuhāt)".

\section{FLOGGING AS A PUNISHMENT IN SAUDI ARABIA}

\section{A Brief Explanation on the Saudi Arabian Criminal Law}

The roots of Saudi Arabia's criminal law can be found in Article 1 of the Law of Criminal Procedures. This article states that the criminal law of the kingdom is mainly based on Shari'ah law and any provision that contradicts to the Shari'ah law principles is abolished by the Shari'ah rules:

Courts shall apply Shari'ah principles, as derived from the Qur'an and Sunnah (Traditions of Prophet Muhammad peace be upon him) to cases brought before them. They shall also apply state promulgated laws that do not contradict the provisions of the Qur'an and Sunnah and 'shall comply with the procedure set forth in this Law. The provisions of this Law shall apply to criminal cases that have not been decided and to proceedings that have not been completed prior to the implementation thereof. ${ }^{34}$

The legal system of Saudi Arabia implements the Shari'ah. However, the kingdom's criminal law follows one of the extremist traditional Islamic penal systems. The judicial system is based on the unlegislated application of the Shari'ah. Any reasoning on the criminal verdict in Saudi Arabia's judicial processes is based on the rules of Fiqh and Islamic Jurisprudence. Saudi Arabia's legal system refers to Shari'ah law, which is derived from the four primary sources of Islam: The Quran, the Sunnah (the word spoken by Prophet Muhammad), Ijma (i.e., Consensus of Muslim counsel), and Qiyas (i.e., Analogy). The application of Islamic law in Saudi Arabian courts is based on the rules

33 "Sunan Ibn Majah. Chapter 23, The Chapters on Legal Punishments, Ahadith co.uk, Accessed December 3, 2020. https://ahadith.co.uk/chapter.php?cid=179\&page $=2 \&$ rows $=10$.

34 "Saudi Law of Criminal Procedure", HR Library, accessed December 12,2020 . http://hrlibrary.umn.edu/research/saudiarabia/criminal_proceedure.html. 
of the Shari'ah as interpreted by the Hanbali school of thought. ${ }^{35}$ The Saudi Constitution has many articles related to the Shariah and criminal law in the country, but the main source for Saudi legislation after the Shari'ah is the Basic Law of governance (1992), which is a de facto Constitution of Saudi Arabia. It is the only codified supreme source of law agreed in Saudi Arabia. Article 45 of the Basic Law of governance (i.e., constitution) states that:

The source of the deliverance of fatwa in the Kingdom of Saudi Arabia is God's Book and the Sunnah of His Messenger. The law will define the composition of the senior ulema body, the administration of scientific research, the deliverance of fatwa and it's (the body of senior ulema's) functions. ${ }^{36}$

Moreover, Article 38 of the Basic Law of Governance asserts that punishments should comply with the Shari'ah. It states that:

No-one shall be punished for another's crimes. No conviction or penalty shall be inflicted without reference to the Sharia or the provisions of the Law. Punishment shall not be imposed ex post facto. ${ }^{37}$

Furthermore, Article 48 of the Basic law asserts that the courts are required to implement the Shari'ah rules that are driven from the primary sources of Islam, i.e., Quran and Sunnah. The said article states that:

The Courts shall apply rules of the Islamic Sharia in cases that are brought before them, according to the Holy Qur'an and the Sunnah, and according to laws which are decreed by the ruler in agreement with the Holy Qur'an and the Sunna. ${ }^{38}$

In spite of the presence of the above-mentioned process of Saudi governance laws, some international organizations have asked the Saudi Government to implement the international obligations that

35 Ansary, Abdullah F., "An Overview of the Saudi Arabian Legal System". https://www.nyulawglobal.org/globalex/Saudi_Arabia1.html\#_Sources_ of_Law.

36 "Basic Law of Governance", The Embassy of the Kingdom of Saudi $\begin{array}{llll}\text { Arabia, } & \text { Accessed } & \text { December } & 12,\end{array}$ https://www.saudiembassy.net/basic-law-governance.

37 "Basic Law of Governance", ibid.

38 Ibid. 
Saudi has obliged itself by. ${ }^{39}$ Article 70 of the Basic Law of Governance is the only provision that mentions the international commitments and obligations that will take place in the internal judicial system. However, the article has not specified the way that those commitments shall be implemented. Contrarily, it asserts that only through the Royal Decree, an international law can be imposed in the Kingdom: "Laws, international agreements, treaties and concessions shall be approved and amended by Royal Decrees." 40

\section{Application of Flogging in Saudi Arabia}

In this section, excerpts from various online sources and data from the official website of the Ministry of Justice have been utilized to evaluate the status and application of flogging in Saudi Arabia. The data from the ministry has revealed various instances where the flogging has been overused, as opposed to the limits prescribed by the Shariah. Moreover, it has been discussed that there is no specific penal court in the country, and codification of punishments in case of various offenses is extremely vague and often open to interpretation by the judges and authorities. Based on this methodology, a comprehensive critical analysis has been made in Section 3.c

There is no penal court in Saudi Arabia and the law of criminal procedure is the only legal guideline for the criminal courts. In 2002, King Fahad agreed to the text of Saudi Arabia's first Law of Criminal Procedure, which was enforced in the same year. ${ }^{41}$ Promulgated in 2002, the law contains 222 articles which are further classified into various parts namely, Preliminary Investigation Procedures, Search of Persons and Dwellings Investigation Procedures, Courts, Trial Proceedings, Objection to Judgments Appeal, Reversal and Reconsideration, Force and Effect of Final Judgment, and Enforceable Judgments.

39 "Saudi Arabia Remains a Fertile Ground for Torture with Impunity". Amnesty International. Accessed December, 15 20200.https://www.refworld.org/pdfid/3ccfbc114.pdf.

40 Ibid

41 Wilcke, Christoph. Precarious Justice: Arbitrary detention and unfair trials in the deficient criminal justice system of Saudi Arabia. Vol. 20, no. 3. Human Rights Watch, 2008. 
As per the Law of Judiciary (1975), the hierarchy of the courts determines Saudi Arabia's judicial structure, where general courts are responsible for criminal cases. Article 22 of Law of Judiciary (1975) states,

Judgments of the General Court shall be rendered by a single judge, except in cases involving death, stoning, and amputation as well as other cases specified by law, where judgment shall be rendered by three judges. In cases where death, stoning, or amputation is inapplicable, the judges handling the case should decide on the appropriate discretionary punishment or otherwise, as required by the Shariah. ${ }^{42}$

On the contrary, Article 125 of the Law of Criminal Procedure states that, "Without prejudice to the jurisdiction of other courts, the criminal court shall have jurisdiction over all criminal cases." 43

It can be observed that the divergence of both these laws creates many inconsistencies and confusions in the prescribed law. For instance, the Law of Criminal Procedure gives authority of criminal cases to the general courts, whereas the Law of Judiciary explicitly gives jurisdiction of all criminal cases to the criminal courts.

It is evident that Saudi Arabia has its Law of Criminal Procedures, but the absence of a penal code hinders the effectiveness of laws. Due to the above-mentioned inconsistencies, a report by Human Rights Watch (HRW) in 2007 described laws in Saudi Arabia as "Saudi vague legal prohibitions". ${ }^{44}$ This report indicates that the application of flogging in Saudi Arabia's criminal law is "inherently cruel and degrading.". ${ }^{45}$ The report emphasized that because of the

42 "Law of Judiciary, Saudi Arabia".The Embassy of the Kingdom of Saudi Arabia Washington D.C. Accessed December 12, 2020 https://www.saudiembassy.net/lawjudiciary\#Third:\%20General\%20Cou rts.

43 "Law of Criminal Procedures 2000". Kingdom of Saudi Arabia Bureau of Experts at the Council of Ministers. Accessed December 15,20200. https://menarights.org/sites/default/files/201612/KSA_LawofCriminalPr ocedures_EN_0.pdf.

44 Wilcke, Christoph. Precarious Justice: Arbitrary detention and unfair trials in the deficient criminal justice system of Saudi Arabia. Vol. 20, no. 3. Human Rights Watch, 2008. Available at hrw.org/reports/2008/saudijustice0308/.

45 Ibid. 
absence of the penal code "The rights and responsibilities of defendants, claimants, and prosecutors remained was vaguely defined." 46 and it concluded that "The lack of a penal code remains a key deficiency in Saudi law and a primary obstacle to protecting Saudi citizens and residents from arbitrary arrest and detention, and unfair trials" ${ }^{47}$

An article published in Riyadh newspaper entitled 'Flogging punishments reached unimaginable numbers' in 2009 raised early questions about flogging as a form of punishment in Saudi Arabia. It brought forth an important question of why the judges in Saudi Arabia overuse flogging and why the number of lashes imposed on the offenders is extremely unreasonable. The article further argued that overuse of flogging depicts the misuse of the Shariah and it particularly quoted an offense which was considered to be punishable by 40,000 lashes, whereas; the maximum number of lashes in a Hudûd offense is only $100 .^{48}$

Another case describing the trajectory of flogging in Saudi Arabia that grabbed the global attention was the Raif Badawi case. According to The New York Times it "set off international outrage". 49 Raif Badawi is a Saudi writer, activist, and creator of the website Free Saudi Liberals. He was arrested in 2012 with a charge of insulting Islam through online platforms. In 2013, he was imprisoned for 7 years and was punished with 600 lashes. In 2014, he was resentenced to 1000 lashes and 10 years in prison and a fine. The lashes were to be carried out over 20 weeks. ${ }^{50}$ In 2015 , he was flogged publicly 50 times as reported.

\footnotetext{
46 Wilcke, Precarious Justice, ibid.

47 Ibid.

48 Hayam Al-Mufleh, "The discrepancy in rulings between judge's needs "legalization the "penalty of flogging" has reached astronomical numbers.", Al Riyadh. April 5, 2009, 14895.

49 Hubbard, B. "Saudi Arabia Abolishes Flogging as a Punishment for Crimes". The New York Times. April 25, 2020.https://www.nytimes.com/2020/04/25/world/middleeast/saudiarabia-abolishes-flogging.html\%20(accessed\%2015/12/2020).

50 "Case History: Raif Badawi". Front Line Defenders. Accessed December 29 2020, https://www.frontlinedefenders.org/en/case/case-history-raifbadawi.
} 
Flogging as a punishment is widely practiced in Saudi Arabia, although the Saudi criminal law is assumed to implement the Shariah. As discussed above, the implementation of flogging is necessary for the punishment of only three Hudûd punishments and it is optional for various Ta'zir offenses.

The Saudi Ministry of Justice claims to publish the collection of judicial rulings of every year, but the latest available version (Year: $2014-1435 \mathrm{H}$ ) is just the collection of two years, which can be accessed on the Ministry website and the Saudi Public Library. ${ }^{51}$ The author of this article has tried to explore the types of offenses that can be punished by flogging, and interestingly most criminal rulings punishable by flogging are combined with imprisonment, fines, or exile (for the non-Saudis particularly).

In the Saudi judicial system, flogging is the punishment for various small and capital offenses. It can be a single punishment, or can be combined with another complementary punishments, such as imprisonment or a fine, and can be implemented publicly and privately. The variety of applications suggest that flogging as a punishment depends upon the interpretation of the judge and his authority, and there are no specific rules to prohibit its overuse. Recently, the decision to abolish flogging has come out by the directive of the Supreme Court. ${ }^{52}$ The order states that flogging will be replaced with imprisonment and fines; however, for the Hudûd offenses, flogging shall not be abolished.

From the available sources that comprise the collections of rulings by the Ministry of Justice has published on its website, the study found the application of flogging against various crimes and offenses. Table 1 shows examples of such application.

51 The researcher has visited three public libraries looking for any other available collections which are King Fahad Library, King Abdul Aziz Public Library and the King Salman Library in King Saud University in Riyadh between 13-11-2020 until 28-12-2020.

52 Hubbard, Benn. 2021. "Saudi Arabia Abolishes Flogging as a Punishment for Crime (Published 4/2020)". Nytimes.com. accessed on March 18, 2021 https://www.nytimes.com/2020/04/25/world/middleeast/saudiarabia-abolishes-flogging.html. 
Table 1: Cases from Collections of 2013- 2014 that involved flogging.

\begin{tabular}{|c|c|c|}
\hline Offence & Punishment & Category \\
\hline Manslaughter $^{53}$ & 450 lashes & $T a^{\prime} z i r$ \\
\hline $\operatorname{larceny}^{54}$ & 300 lashes & Ta'zir \\
\hline $\begin{array}{l}\text { Not attend prayer in } \\
\text { congregation (without } \\
\text { excuse) }\end{array}$ & 50 lashes & Ta'zir \\
\hline $\begin{array}{l}\text { Disobedience to } \\
\text { parents \& drinking }{ }^{56}\end{array}$ & $\begin{array}{l}150 \text { lashes for } \\
\text { disobedience to } \\
\text { parent } \\
80 \text { lashes for } \\
\text { drinking }\end{array}$ & $T a^{\prime} z i r$ \\
\hline Possess a gun ${ }^{57}$ & 40 lashes & Ta'zir \\
\hline Criminal threatening $^{58}$ & $\begin{array}{l}50 \text { lashes } 3 \text { times } \\
\text { in public. }\end{array}$ & Ta'zir \\
\hline
\end{tabular}

53 Judicial Judgments Collection, 1434, Volume 13, Case No. 4944. P5.

54 Ibid, Case Number: 342326 date:21/4/1434H (2013) C1434 Volume.25 P.47.

55 Ibid, Case number: 33563958 date:13/11/1433H (2012) C1434 Volume.25 P.35.

56 In this case two offences have been made, one of the from Hudud (Drinking) and its Punishment is 80 lashes. the second one is Disobedience to parents and punished by 6-month imprisonment and 150 lashes.

57 Judicial Judgments Collection, Collection 1434 Volume 24 Case number: 341143855 date: 9/4/1434 P.227 In this case the defendant was juvenile (15 years old).

58 Ibid, Case number: 33708489 date: 18/1/1433 C1434 Volume 24 P.72. 


\begin{tabular}{|c|c|c|}
\hline Drifting $^{59}$ & 40 lashes & Ta'zir \\
\hline Attempt to murder ${ }^{60}$ & 250 lashes & Ta'zir \\
\hline $\begin{array}{l}\text { Blackmail - } \\
\text { Cyber Crime }^{61}\end{array}$ & 200 lashes & Ta'zir \\
\hline Sodomy $^{62}$ & 100 lashes & Ta'zir \\
\hline Sale porn materials ${ }^{63}$ & 120 lashes & Ta'zir \\
\hline Drug smuggling ${ }^{64}$ & 1500 lashes & Ta'zir \\
\hline Witchcraft $^{65}$ & $\begin{array}{l}300 \text { lashes in } \\
\text { public }\end{array}$ & Ta'zir \\
\hline Drug Use ${ }^{66}$ & $\begin{array}{l}80 \text { lashes in } \\
\text { public }\end{array}$ & Hadd \\
\hline Slander ${ }^{67}$ & 70 lashes & Ta'zir \\
\hline Perjury $^{68}$ & 40 lashes & Ta'zir \\
\hline
\end{tabular}

The application of flogging in Saudi Arabia reveals a variety of issues in Saudi Arabia's legal system. Firstly, flogging is the most widely used punishment for different offenses; mainly, for the immoral acts. Flogging is implemented in combination with imprisonment and fines and, oftentimes, the number of lashes also exceeds the prescribed limits set by the Shari'ah. Furthermore, its public implementation and clear

\footnotetext{
59 Ibid, Case number: 34169778 date: 18-71434 C1434 Volume 24 P.40.

60 Ibid, Case number: 34272186 date: 17/7/1434 C1434 Volume 13 P.173.

61 Ibid, Case number: 34219003 date: 28/5/1434 C1434 Volume 24 P.139.

62 Ibid, Case number: 35153214 C1435 Volume 11 P.5.

63 Ibid, Case number: 3428575 date: 16/2/1434 C1434 Volume 24 P.87.

64 Ibid, Case number: 3467642 date: 1434 C1435 Volume 11 P.451.

65 Ibid, Case number: 3314615 date: 1433 C1435 Volume 12 P.336.

66 Ibid, Case number: 3583083 date: 1435 C1435 Volume 12 P.55.

67 Ibid, Case number: 3544511 date: 1435 C1435 Volume 11 P.235.

68 Ibid, Case number: 34242667 date:17/71434 C1434 Volume 24 P.13.
} 
directives for public implementation in the verdict are also serious concerns. Furthermore, the judges in Saudi Arabia have the authority to impose lashes but there is no limit on the number of lashes. The concept of Ta'zir gives judges the authority to choose the proper punishment for the wrongful act or an offense. This decision represents the prospects of a more reconciled, reviewed, and amended Saudi judicial system that will be consistent with the practices of international human rights law and the Shari'ah.

\section{SOME OBSERVATIONS}

In this study, various aspects of flogging have been described. First, the international laws and treaties have been cited to determine that flogging is an act of torture and can be described as an inhuman and degrading punishment inflicted against any human being. Second, the historical implementation of flogging in Islamic world and its presence in the Shari'ah has been discussed. Third, the Saudi Arabia's Criminal Law system and situation of flogging as punishment has been detailed. Although it is observed that, the criminal code in Saudi Arabia prevents torture, it is extremely common to use torture to obtain confessions.

It can be summed that flogging in Saudi Arabia is often altered from the Shari'ah position. There is a discrepancy between the application and jurisdiction in case of Saudi and non-Saudi citizens. Moreover, the application of flogging in various criminal cases is extremely open to the interpretation of judges; and in most cases, the number of lashes easily exceed the prescribed number of lashes (maximum 100 lashes) prescribed in the Shari'ah. For instance, Table 1 provides many offenses, where the number of lashes exceed far beyond 100 .

Finally, the article contemplates over the need for a clear and well-defined codification of criminal law in Saudi Arabia. For instance, the number of lashes can be combined with various forms of other punishments including exile, fines, and imprisonment. In this respect, the case of Raif Badawi can be cited to highlight the lack of uniformity and discrepancies in the application of law. ${ }^{69}$ Summarily, it can be

69 See: Saudi Public Prosecutor V Raif Badawi, Global Freedom of Expression, Columbia University. Accessed 29/5/2021 
determined that codification of law and transparency in the implementation are visible problems in the Saudi criminal justice system. There is an evident need for reforms on massive scale. Not only are these punishments not compliant with the international laws, neither is it in line with the Shari'ah.

Another aspect of flogging (or caning) as a form of punishment in the Kingdom is that the current method of implementing the punishment clearly conflicts with many international treaties and laws. Interestingly, Saudi Arabia is a signatory or member of many of these laws, and is constantly under the scrutiny of international human rights organizations. However, in all the cases where the international human rights organizations question the domestic laws in Saudi Arabia, the reviews or calls for reforms are precluded or postponed by the Saudi authorities under the pretext of abiding by the Shari'ah and sovereignty. Due to the authoritarian nature of Saudi government, the Royal Decree has been granted the power to amend international agreements, treaties and concessions. Most of these issues are in direct inconsistencies with Articles 5, 7, 10, and 11 of the Universal Declaration of Human Rights. According to the 2020 report published by Human Rights Watch (HRW), several incidents of torture and human rights violations have been cited. However, owing to the immense pressure from the global community and the defenders of human rights, Saudi Arabia's Ministry of Justice has announced the prohibition of flogging in Ta'azir punishments. ${ }^{70}$ This announcement can be witnessed as a sign of Saudi Arabia's intention to reform its judicial system. Moreover, it is a positive, progressive, and encouraging sign to bring Saudi Arabia in line with the International human rights. This development can be attributed to the relentless efforts of the International NGOs, Advocates of Human rights, and other international stakeholders who have helped to bring about this significant change.

https://globalfreedomofexpression.columbia.edu/cases/saudi-publicprosecutor-v-raif-badawi/.

70 See "World Report 2020: Rights Trends in Saudi Arabia". Human Rights Watch. Accessed 18 May2020, https://www.hrw.org/worldreport/2020/country-chapters/saudi-arabia\#. 


\section{CONCLUSION}

Flogging has been used in different religions, cultures, and legal systems throughout history. However, its use has been a subject of continuous debate among proponents of human rights. Saudi Arabia is one of the countries that extensively use flogging as a punishment. Its application is widely criticized by various human rights organizations and international human rights agencies. This research study has investigated the implementation of flogging in Saudi Arabia's judicial system. Overall, it is concluded that the implementation of flogging in Saudi Arabia is characterized by overuse and uncodified rules and regulations. Flogging in Saudi Arabia is broadly used to punish different kinds of offenses, which is not only against the international human rights laws, but also no align with the Shari'ah.

This excessive application of such punishment reflects the extent of the imbalance produced by the expansion of the judge's authority, and his ability to interpret and diligence, which in this case, for example, did not take into account the interest and the main objective of the punishment, which is the deterrence and not torture, the best interests of society and the philosophy of punishment in Islam.

This article wishes to highlight that there is a necessity of criminal law codification based on the Shari'ah in Saudi Arabia. The latest decision to remove flogging form Ta'azir punishments will be significant for the law makers to reconsider the penal code and that could help judges to refrain from exceeding any limits that the code will give. This, could very well lead to a more stable and fair punishments in the Kingdom. 